\title{
Measuring productivity change accounting for adjustment costs: evidence from the food industry in the European Union
}

\author{
Magdalena Kapelko1 ${ }^{1}$
}

Published online: 28 April 2017

(C) The Author(s) 2017. This article is an open access publication

\begin{abstract}
This paper extends the measurement of dynamic productivity change over time to provide its full decomposition into economically meaningful components in the Data Envelopment Analysis framework. The dynamic approach accounts for dynamics of production decisions via adjustment costs and is visualized as a dynamic Luenberger productivity change indicator. The paper also estimates the dynamic productivity change and its components for a large dataset of European food companies from 2004 till 2012, grouped into Eastern, Southern, and Western regions. The study reveals three main results. First, the overall trend of dynamic technical regress and positive dynamic technical inefficiency change across almost all regions and sectors was found. Second, some differences for this general pattern were found for the bakery industry and for Eastern European firms. Thirdly, there are also some remarkable changes in indicators observed during the periods related to the financial crisis and the volatility of agricultural commodity prices.
\end{abstract}

Keywords Data envelopment analysis · Dynamic productivity growth · Dynamic Luenberger indicator $\cdot$ Food manufacturing industry

\section{Introduction}

The food manufacturing sector in the European Union (EU) (together with the drink industry) accounts for $2 \%$ of the gross value added created by all economic sectors of the EU in 2012 (Eurostat 2016a). It is the largest manufacturing sector in the EU representing $15 \%$ of total manufacturing turnover, $14 \%$ of the total number of companies, and $15 \%$ of total employment in 2012 (European Commission 2016). The food manufacturing industry encompasses a variety of products and its most important subsectors with regard to turnover are: meat processing and production of meat products, processing of fruit and vegetables, manufacture

Magdalena Kapelko

magdalena.kapelko@ue.wroc.pl

1 Department of Logistics, Institute of Applied Mathematics, Wroclaw University of Economics, ul. Komandorska 118/120, 53-345 Wroclaw, Poland 
of dairy products, and manufacture of bakery and farinaceous products (Eurostat 2016b). Table 1 provides some important statistics about the food manufacturing sector and its main subsectors. The table indicates that the main turnover producing sector is meat manufacturing, although bakery manufacturing leads in terms of employment and the number of enterprises.

Several trends and challenges have affected the development of this sector in the last decade. The most significant shock is the 2008 global financial crisis, which resulted in decreasing trend in household expenditure on food products from 2009 onwards (European Commission 2016). The impact of financial crisis can be seen in Table 1, which shows that turnover, employment, and number of enterprises dropped in 2009 in almost all subsectors of food manufacturing. An interesting exception was the dairy manufacturing sector, which managed to augment employment in 2009 despite reducing its number of enterprises. The food manufacturing industry is also influenced by agricultural commodity prices determining firms' production costs, which have been very volatile since mid-2007 (European Commission 2016). This refers mainly to the dairy manufacturing sector, which is dependent on milk prices, and the bakery sector, which relies on the input of grain and cereals. Also, the exposure to external competition following the globalization and liberalization of food markets is on rise in the EU food manufacturing sector (European Commission 2011). In this industry, the last decade has also seen a change in consumer preferences towards healthy foods, socially responsible consumption, and organic foods (European Commission 2016, 2011). Finally, the last decade has also been characterized by the implementation of the General Food Law (Regulation (EC) No 178/2002), the EU regulation regarding food safety. In this context, it is worthwhile to benchmark the performance and productivity change of the food manufacturing industry to assess its evolution and firms' productivity change resiliency or susceptibility to the aforementioned challenges and shocks.

Table 1 Statistics regarding food manufacturing and its main subsectors in the European Union. Source Eurostat (2016b)

\begin{tabular}{|c|c|c|c|c|}
\hline Variable and sector & 2008 & 2009 & 2010 & 2011 \\
\hline \multicolumn{5}{|l|}{ Turnover (millions of Euros) } \\
\hline Food manufacturing & 846,943 & 783,023 & 813,590 & 871,400 \\
\hline Meat manufacturing & 190,000 & 185,000 & 191,000 & 200,000 \\
\hline Fruit and vegetable processing & - & 56,000 & 58,000 & 62,757 \\
\hline Dairy manufacturing & 139,489 & 120,000 & 130,000 & 142,932 \\
\hline Bakery manufacturing & 111,906 & 106,654 & 108,728 & 110,953 \\
\hline \multicolumn{5}{|l|}{ Employment } \\
\hline Food manufacturing & $4,077,100$ & $3,977,000$ & $4,091,500$ & $4,075,400$ \\
\hline Meat manufacturing & 938,400 & 904,900 & 948,300 & 930,300 \\
\hline Fruit and vegetable processing & 262,100 & 256,100 & 260,000 & 259,000 \\
\hline Dairy manufacturing & 358,400 & 365,800 & 360,000 & 365,500 \\
\hline Bakery manufacturing & $1,515,900$ & $1,452,500$ & $1,525,900$ & $1,525,500$ \\
\hline \multicolumn{5}{|l|}{ Number of enterprises } \\
\hline Food manufacturing & 268,768 & 252,335 & 264,130 & 262,816 \\
\hline Meat manufacturing & 41,300 & 36,766 & 40,000 & 38,300 \\
\hline Fruit and vegetable processing & 10,119 & 9961 & 10,275 & 10,093 \\
\hline Dairy manufacturing & 11,766 & 11,639 & 11,745 & 12,578 \\
\hline Bakery manufacturing & 157,722 & 146,632 & 154,157 & 154,547 \\
\hline
\end{tabular}


In principle, the development of productivity change of the economic sector can be analyzed from the static or dynamic perspective. In the static productivity change measures, represented for example by the static Malmquist index (Färe et al. 1992; applied, for example, in Lv et al. 2015) or the static Luenberger indicator (Chambers et al. 1996; Chambers and Pope 1996; applied, for example, in Williams et al. 2011), it is assumed that firms' production decisions are not linked over time and firms' capital or other quasi-fixed inputs are treated as fixed. However, recent literature has recognized the importance of accounting for the dynamics of firms' production decisions in the measures of firms' productivity change, especially in the presence of adjustment $\operatorname{costs}^{1}$ that arise from the changes in quasi-fixed factors of production associated with investments in these factors (Silva and Stefanou 2003, 2007). ${ }^{2}$ In order to do this, the dynamic Luenberger indicator has been developed (Oude Lansink et al. 2015). The usage of dynamic measures is especially important in the case of the food manufacturing industry, which lacks short-run flexibility due to adjustment costs. This industry is also relatively capital-intensive and numerous studies have recognized the importance of modeling the quasi-fixed nature of capital for this industry (Morrison Paul 1997, 2001a,b).

Several studies have focused on productivity change of the food manufacturing industry in different contexts and evidence tends to show the productivity and efficiency growth, with mixed findings regarding technical change. In the context of Australian broad-acre beef production enterprises, Gregg and Rolfe (2011) found strong productivity growth due to technological progress and technical and scale efficiency improvements. Also in the Australian context, Doucouliagos and Hone (2001) found moderate productivity growth for the dairy processing industry, mainly driven by technical progress. Several studies have analyzed the Indian food manufacturing industry, finding productivity growth, efficiency decrease, and technical progress (Jabir et al. 2009; Ohlan 2013), but also technical regress (Kumar and Basu 2008). For the South Korean food manufacturing industry, Kim and Han (2001) found technical progress, negative scale efficiency change, and productivity growth. Bontemps et al. (2012) found technical regress for French cheese and poultry production. The findings for the US dairy manufacturing sector show negative productivity growth, with both scale and technical change effects contributing negatively (Geylani and Stefanou 2011). The US food manufacturing industry was also analyzed by Morrison Paul (1997), who reported overall productivity growth, with exceptions of productivity decline for some periods. Also in the US context, Buccola et al. (2000) reported a slight negative productivity growth for the bakery products industry. In the context of Greek dairy manufacturing, Vlontzos and Theodoridis (2013) found a positive productivity growth. Dynamic productivity growth of the Spanish food manufacturing industry has been analyzed by Kapelko et al. (2015a, 2017a)

\footnotetext{
1 Adjustment costs represent transaction or reorganization costs, such as learning costs. In most dynamic efficiency proposals, such as those in Silva and Stefanou (2003, 2007), these adjustment cost are explicitly modeled. The exception in the efficiency literature is De Mateo et al. (2006), which looked at adjustment costs in ex-ante context. Historically and in economic theory literature, the theory of adjustment costs is developed by Treadway (1970).

2 This approach to the measurement of dynamic efficiency and productivity change can be referred to as adjustment cost theory-based approach. The alternative strand of literature within this line of research consists of the studies of dynamic network Data Envelopment Analysis (DEA) (see, for example, Färe and Grosskopf 1996; Kao 2013; Tone and Tsutsui 2014). The dynamic network DEA has been recently extended to a dynamic network Luenberger indicator in the study of Fukuyama and Weber (2017). There is also one more framework of dynamic DEA that considers quasi-fixed inputs as outputs in the current period and as inputs in the next period (see, for example, Nemoto and Goto 1999; Von Geymueller 2009). Finally, the studies that introduce quasi-fixed inputs in the DEA measures (see, for example, Ouellette and Vierstraete 2010) are also associated with this line of research.
} 
(meat and dairy processing and oils and fats industries), Kapelko et al. (2015b) (meat processing industry), and Kapelko et al. (2016) (meat processing and oils and fats industries); all of these studies found that average productivity is very close to zero, with its components telling a story of negative technical change, and positive technical inefficiency change and scale inefficiency change. Kapelko et al. (2017b) reached similar conclusions regarding static productivity growth in the Spanish dairy processing industry. It is worth noting that all of the aforementioned studies have focused on food manufacturing sector in one country or region and no studies have analyzed productivity growth in several countries or regions simultaneously.

The present study takes a dynamic adjustment perspective on productivity change and measures productivity change of food manufacturing industry (meat manufacturing, fruit and vegetable processing, dairy manufacturing, and bakery manufacturing) over the 20052012 period for 18 EU countries, grouped into Eastern, Southern and Western regions. For this purpose, the dynamic Luenberger indicator developed by Oude Lansink et al. (2015) is extended to provide its full decomposition into dynamic technical inefficiency change, dynamic scale inefficiency change, dynamic technical change, and scale change of dynamic technology in the Data Envelopment Analysis (DEA) framework.

This study contributes to the literature in at least two ways. First, it extends the dynamic Luenberger indicator to provide its full decomposition into economically meaningful components. Second, it empirically demonstrates the applicability of this decomposition using the large dataset of European food manufacturing firms in EU regions; this makes it, to the best of our knowledge, the first study to analyze dynamic productivity growth of this sector in different European regions.

The rest of this paper is organized as follows. Section 2 develops the methodology of dynamic Luenberger indicator and shows its empirical implementation using DEA. Section 3 provides details about the dataset used in this study. The results are discussed in Sect. 4, while Sect. 5 concludes.

\section{Methodology}

\subsection{Dynamic Luenberger productivity growth indicator and its decomposition}

The efficiency and productivity literature distinguishes two main productivity change indicators: the Malmquist index (Färe et al. 1992) which is a ratio-based measure of the Shephard distance functions (Shephard 1953); and the Luenberger indicator (Chambers et al. 1996; Chambers and Pope 1996), which is a difference-based measure of directional distance functions (Chambers et al. 1998). The directional distance function is a version of the Luenberger's benefit function (Luenberger 1992, 1995) and the Luenberger's shortage function (Luenberger 1992, p. 242, Definition 4.1), which were redefined as efficiency measures by Chambers et al. (1998) leading to the definition of directional distance function. Benefit function represents the amount that an individual is willing to trade, in terms of a specific reference commodity bundle $\mathrm{g}$, for the opportunity to move from a consumption bundle to a utility threshold, while the shortage function measures the amount by which a specific production plan is short of reaching the frontier of the technology. Although the directional distance function does not generalize all the existing distance functions, such as the Hölder distance function of Briec (1998) and the weighted additive distance function of Aparicio et al. 
(2016) ${ }^{3}$ However, it is flexible to account for both input contractions and output improvements and is also able to focus on an input-oriented or output-oriented perspective as well as it allows for flexibility in choosing the directional vector (Boussemart et al. 2003). Therefore, the present paper uses a Luenberger-type indicator to assess productivity change over time.

Until recently, the Luenberger indicator was only developed in a static context, in which firms can adjust production decisions instantaneously. Oude Lansink et al. (2015) defined a dynamic Luenberger indicator that accounts for the dynamic nature of firms' production decisions through adjustment costs related to firms' investments. The dynamic Luenberger indicator was subsequently extended by Kapelko et al. (2015a) and applied elsewhere (Kapelko et al. 2015b, 2016, 2017a).

The dynamic Luenberger indicator and its decomposition components are now developed. To this end, it is necessary to introduce some notation and basic concepts. Consider a data series $\left(\mathbf{y}_{t}, \mathbf{k}_{t}, \mathbf{x}_{t}, \mathbf{I}_{t}\right)$ that represents the observed behavior of $\mathrm{j}=1, \ldots, J$ firms at time $t$ that produce $M$ outputs $\left(\mathbf{y}_{t}\right)$, using $F$ quasi-fixed factors $\left(\mathbf{k}_{t}\right), N$ variable inputs $\left(\mathbf{x}_{t}\right)$, and $F$ gross investments $\left(\mathbf{I}_{t}\right)$. The same firms are observed at time $t+1$, and their inputs, outputs and investments are denoted as: $\left(\mathbf{y}_{t+1}, \mathbf{k}_{t+1}, \mathbf{x}_{t+1}, \mathbf{I}_{t+1}\right)$. The dynamic directional input distance function for time $t$ is defined as follows (Kapelko et al. 2014; Silva et al. 2015):

$$
\begin{aligned}
& \vec{D}_{t}^{i}\left(\mathbf{y}_{t}, \mathbf{k}_{t}, \mathbf{x}_{t}, \mathbf{I}_{t} ; \mathbf{g}_{x}, \mathbf{g}_{I}\right)=\max \left\{\beta \in \Re:\left(\mathbf{x}_{t}-\beta \mathbf{g}_{x}, \mathbf{I}_{t}+\beta \mathbf{g}_{I}\right) \in P_{t}\left(\mathbf{y}_{t}: \mathbf{k}_{t}\right)\right\} \quad \text { if } \\
& \left(\mathbf{x}_{t}-\beta \mathbf{g}_{x}, \mathbf{I}+\beta \mathbf{g}_{I}\right) \in P_{t}\left(\mathbf{y}_{t}: \mathbf{k}_{t}\right) \text { for some } \beta, \\
& \vec{D}_{t}^{i}\left(\mathbf{y}_{t}, \mathbf{k}_{t}, \mathbf{x}_{t}, \mathbf{I}_{t} ; \mathbf{g}_{x}, \mathbf{g}_{I}\right)=-\infty, \text { otherwise. }
\end{aligned}
$$

where $\mathbf{g}_{x} \in \mathfrak{R}_{++}^{N}$ and $\mathbf{g}_{I} \in \mathfrak{R}_{++}^{F}$ are non-zero vectors determining the direction for variable inputs and investments, $\beta$ is a measure of dynamic technical inefficiency, and $P_{t}\left(\mathbf{y}_{t}: \mathbf{k}_{t}\right)$ is the input requirement set (representing the dynamic production technology) that is defined as (Silva and Stefanou 2003):

$$
P_{t}\left(\mathbf{y}_{t}: \mathbf{k}_{t}\right)=\left\{\left(\mathbf{x}_{t}, \mathbf{I}_{t}\right) \text { can produce } \mathbf{y}_{t}, \text { given } \mathbf{k}_{t}\right\}
$$

The dynamic directional input distance function is defined by simultaneously contracting variable inputs in the direction $\left(\boldsymbol{g}_{x}\right)$ and expanding gross investments in the direction $\left(\boldsymbol{g}_{I}\right)$ as investments allow for cost savings in the long run. ${ }^{4}$ The dynamic directional input distance function for time $t+1, \vec{D}_{t+1}^{i}\left(\mathbf{y}_{t+1}, \mathbf{k}_{t+1}, \mathbf{x}_{t+1}, \mathbf{I}_{t+1} ; \mathbf{g}_{x}, \mathbf{g}_{I}\right)$ is defined similarly to (1). Also, the mixed period dynamic directional input distance functions, which reflect the technology at time $t$ evaluated using observations at time $t+1, \vec{D}_{t}^{i}\left(\mathbf{y}_{t+1}, \mathbf{k}_{t+1}, \mathbf{x}_{t+1}, \mathbf{I}_{t+1} ; \mathbf{g}_{x}, \mathbf{g}_{I}\right)$, and the technology at time $t+1$ evaluated using observations at time $t, \vec{D}_{t+1}^{i}\left(\mathbf{y}_{t}, \mathbf{k}_{t}, \mathbf{x}_{t}, \mathbf{I}_{t} ; \mathbf{g}_{x}, \mathbf{g}_{I}\right)$, are defined similarly to (1).

Next, the dynamic directional input distance functions can be used to compute productivity changes between periods $t$ and $t+1$ using the dynamic Luenberger indicator (Oude Lansink et al. 2015), as follows:

$$
L=\frac{1}{2}\left\{\begin{array}{l}
{\left[\vec{D}_{t+1}^{i}\left(\mathbf{y}_{t}, \mathbf{k}_{t}, \mathbf{x}_{t}, \mathbf{I}_{t} ; \mathbf{g}_{x}, \mathbf{g}_{I}\right)\left|C R S-\vec{D}_{t+1}^{i}\left(\mathbf{y}_{t+1}, \mathbf{k}_{t+1}, \mathbf{x}_{t+1}, \mathbf{I}_{t+1} ; \mathbf{g}_{x}, \mathbf{g}_{I}\right)\right| C R S\right]} \\
+\left[\vec{D}_{t}^{i}\left(\mathbf{y}_{t}, \mathbf{k}_{t}, \mathbf{x}_{t}, \mathbf{I}_{t} ; \mathbf{g}_{x}, \mathbf{g}_{I}\right)\left|C R S-\vec{D}_{t}^{i}\left(\mathbf{y}_{t+1}, \mathbf{k}_{t+1}, \mathbf{x}_{t+1}, \mathbf{I}_{t+1} ; \mathbf{g}_{x}, \mathbf{g}_{I}\right)\right| C R S\right]
\end{array}\right\}
$$

The first two terms in (3) reflect the dynamic productivity change measured by the technology at time $t+1$, while the last two terms in (3) indicate dynamic productivity change measured by

\footnotetext{
3 In addition, recently, Aparicio et al. (2017) showed that while directional distance function correctly embeds the technical efficiency of the Farrell approach, this is not true for the allocative efficiency.

4 There is also the dynamic directional technology distance function, which involves a contraction of variable inputs and simultaneously an expansion of investments and outputs, and the dynamic directional output distance function that represents the maximum possible expansion of the output vector.
} 
the technology at time $t$; dynamic Luenberger indicator is an arithmetic average of these two productivity changes. In the computation of (3) constant returns to scale (CRS) are assumed.

The dynamic Luenberger indicator has so far been decomposed into the contributions of dynamic technical change (T), dynamic technical inefficiency change under variable returns to scale (VRS) (TIEV) and dynamic scale inefficiency change (SIE) (Kapelko et al. 2015a):

$$
L=T+T I E V+S I E
$$

Dynamic technical change is computed as the arithmetic average of the difference between the technology at time $t$ and time $t+1$ using the observations at time $t$ and time $t+1$ :

$$
T=\frac{1}{2}\left\{\begin{array}{l}
{\left[\vec{D}_{t+1}^{i}\left(\mathbf{y}_{t}, \mathbf{k}_{t}, \mathbf{x}_{t}, \mathbf{I}_{t} ; \mathbf{g}_{x}, \mathbf{g}_{I}\right)\left|C R S-\vec{D}_{t}^{i}\left(\mathbf{y}_{t}, \mathbf{k}_{t}, \mathbf{x}_{t}, \mathbf{I}_{t} ; \mathbf{g}_{x}, \mathbf{g}_{I}\right)\right| C R S\right]} \\
+\left[\vec{D}_{t+1}^{i}\left(\mathbf{y}_{t+1}, \mathbf{k}_{t+1}, \mathbf{x}_{t+1}, \mathbf{I}_{t+1} ; \mathbf{g}_{x}, \mathbf{g}_{I}\right) \mid C R S\right. \\
\left.-\vec{D}_{t}^{i}\left(\mathbf{y}_{t+1}, \mathbf{k}_{t+1}, \mathbf{x}_{t+1}, \mathbf{I}_{t+1} ; \mathbf{g}_{x}, \mathbf{g}_{I}\right) \mid C R S\right]
\end{array}\right\}
$$

Dynamic technical change measures the shift of best practice dynamic production technology defined by the reduction of variable inputs and the expansion of investments between two periods of time. In (5), dynamic technical change is defined with regard to CRS technology. Dynamic technical inefficiency change is computed as the difference between the value of the dynamic directional distance function in VRS at time $t$ and time $t+1$ :

$$
T I E=\vec{D}_{t}^{i}\left(\mathbf{y}_{t}, \mathbf{k}_{t}, \mathbf{x}_{t}, \mathbf{I}_{t} ; \mathbf{g}_{x}, \mathbf{g}_{I} \mid V R S\right)-\vec{D}_{t+1}^{i}\left(\mathbf{y}_{t+1}, \mathbf{k}_{t+1}, \mathbf{x}_{t+1}, \mathbf{I}_{t+1} ; \mathbf{g}_{x}, \mathbf{g}_{I} \mid V R S\right)
$$

Dynamic technical inefficiency change assesses whether the evaluated firm is getting closer to or further away from the best practice dynamic production technology in VRS between two periods of time.

Dynamic scale inefficiency change is computed as the difference between dynamic directional distance functions relative to CRS technology and these relative to VRS technology between periods $t$ and $t+1$ :

$$
\begin{aligned}
S I E= & \vec{D}_{t}^{i}\left(\mathbf{y}_{t}, \mathbf{k}_{t}, \mathbf{x}_{t}, \mathbf{I}_{t} ; \mathbf{g}_{x}, \mathbf{g}_{I} \mid C R S\right)-\vec{D}_{t}^{i}\left(\mathbf{y}_{t}, \mathbf{k}_{t}, \mathbf{x}_{t}, \mathbf{I}_{t} ; \mathbf{g}_{x}, \mathbf{g}_{I} \mid V R S\right) \\
& -\left[\vec{D}_{t+1}^{i}\left(\mathbf{y}_{t+1}, \mathbf{k}_{t+1}, \mathbf{x}_{t+1}, \mathbf{I}_{t+1} ; \mathbf{g}_{x}, \mathbf{g}_{I} \mid C R S\right)\right. \\
& \left.-\vec{D}_{t+1}^{i}\left(\mathbf{y}_{t+1}, \mathbf{k}_{t+1}, \mathbf{x}_{t+1}, \mathbf{I}_{t+1} ; \mathbf{g}_{x}, \mathbf{g}_{I} \mid V R S\right)\right]
\end{aligned}
$$

Dynamic scale inefficiency change reflects changes in the dynamic scale inefficiency of a production unit, and measures the movement of the evaluated firms towards or away from the optimal scale, which is the difference between position of the firm with regard to CRS technology and VRS technology between two periods of time.

In order to obtain the meaningful economic interpretation of all components of dynamic productivity change, it is desirable to assume VRS technology when computing dynamic technical change. In fact, although several studies support the computation of technical change using VRS technology, they are all in the context of Malmquist index; these include Simar and Wilson (1998), Zofio and Lovell (1998), Wheelock and Wilson (1999) and Zofio (2007). This point leads to the further decomposition of dynamic technical change component $T$ in (4) into technical change under VRS (TV) and the residual measure that can be called the scale change of dynamic technology $(S T)$ (that is, $T=T V+S T$ ). To the best of our knowledge, this further decomposition of technical change has never been developed or applied in the context of Luenberger indicator (neither for static nor dynamic Luenberger indicators). Therefore, the final decomposition of dynamic productivity change can be written as:

$$
L=T V+S T+T I E V+S I E
$$


This decomposition reveals the whole picture of dynamic Luenberger indicator regarding the changes in dynamic technology and efficiency.

Dynamic technical change under VRS (TV) is computed similarly to (5); that is, as the arithmetic average of the difference between the technology at time $t$ and time $t+1$ using the quantities at time $t$ and time $t+1$ :

$$
T V=\frac{1}{2}\left\{\begin{array}{l}
{\left[\vec{D}_{t+1}^{i}\left(\mathbf{y}_{t}, \mathbf{k}_{t}, \mathbf{x}_{t}, \mathbf{I}_{t} ; \mathbf{g}_{x}, \mathbf{g}_{I}\right)\left|V R S-\vec{D}_{t}^{i}\left(\mathbf{y}_{t}, \mathbf{k}_{t}, \mathbf{x}_{t}, \mathbf{I}_{t} ; \mathbf{g}_{x}, \mathbf{g}_{I}\right)\right| V R S\right]} \\
+\left[\vec{D}_{t+1}^{i}\left(\mathbf{y}_{t+1}, \mathbf{k}_{t+1}, \mathbf{x}_{t+1}, \mathbf{I}_{t+1} ; \mathbf{g}_{x}, \mathbf{g}_{I}\right) \mid V R S\right. \\
\left.-\vec{D}_{t}^{i}\left(\mathbf{y}_{t+1}, \mathbf{k}_{t+1}, \mathbf{x}_{t+1}, \mathbf{I}_{t+1} ; \mathbf{g}_{x}, \mathbf{g}_{I}\right) \mid V R S\right]
\end{array}\right\}
$$

Dynamic technical change under VRS indicates the shifts of the best-practice VRS dynamic production technology between two periods of time, which relates variable inputs, quasi-fixed inputs, and investments to the production of outputs.

Scale change of dynamic technology $(S T)$ is computed as follows:

$$
S T=\frac{1}{2}\left\{\begin{array}{l}
{\left[\vec{D}_{t+1}^{i}\left(\mathbf{y}_{t+1}, \mathbf{k}_{t+1}, \mathbf{x}_{t+1}, \mathbf{I}_{t+1} ; \mathbf{g}_{x}, \mathbf{g}_{I}\right) \mid C R S\right.} \\
\left.-\vec{D}_{t+1}^{i}\left(\mathbf{y}_{t+1}, \mathbf{k}_{t+1}, \mathbf{x}_{t+1}, \mathbf{I}_{t+1} ; \mathbf{g}_{x}, \mathbf{g}_{I}\right) \mid V R S\right] \\
-\left[\vec{D}_{t}^{i}\left(\mathbf{y}_{t+1}, \mathbf{k}_{t+1}, \mathbf{x}_{t+1}, \mathbf{I}_{t+1} ; \mathbf{g}_{x}, \mathbf{g}_{I}\right) \mid C R S\right. \\
\left.-\vec{D}_{t}^{i}\left(\mathbf{y}_{t+1}, \mathbf{k}_{t+1}, \mathbf{x}_{t+1}, \mathbf{I}_{t+1} ; \mathbf{g}_{x}, \mathbf{g}_{I}\right) \mid V R S\right] \\
+\left[\vec{D}_{t+1}^{i}\left(\mathbf{y}_{t}, \mathbf{k}_{t}, \mathbf{x}_{t}, \mathbf{I}_{t} ; \mathbf{g}_{x}, \mathbf{g}_{I}\right)\left|C R S-\vec{D}_{t+1}^{i}\left(\mathbf{y}_{t}, \mathbf{k}_{t}, \mathbf{x}_{t}, \mathbf{I}_{t} ; \mathbf{g}_{x}, \mathbf{g}_{I}\right)\right| V R S\right] \\
-\left[\vec{D}_{t}^{i}\left(\mathbf{y}_{t}, \mathbf{k}_{t}, \mathbf{x}_{t}, \mathbf{I}_{t} ; \mathbf{g}_{x}, \mathbf{g}_{I}\right)\left|C R S-\vec{D}_{t}^{i}\left(\mathbf{y}_{t}, \mathbf{k}_{t}, \mathbf{x}_{t}, \mathbf{I}_{t} ; \mathbf{g}_{x}, \mathbf{g}_{I}\right)\right| V R S\right]
\end{array}\right\}
$$

Scale change of dynamic technology is the arithmetic average of two differences. The first two terms in the first difference reflect a measure of dynamic scale inefficiency in time $t+1$ (that is, a distance between CRS and VRS in time $t+1$ relative to observations in $t+1$ and are identical to the last two terms in the measure of dynamic scale inefficiency change shown by (7). The last two terms in the first difference are similar to the first two terms, but the technology refers to period $t$, while observations still refer to $t+1$. Therefore, the first difference measures the change in the scale (shape) of dynamic technology between time $t$ and $t+1$ relative to observations in time $t+1$. Accordingly, the second difference assesses the change in the scale of the dynamic technology between $t$ and $t+1$ relative to observations at time $t$.

Scale change of dynamic technology reflects the shift in the optimal scale of dynamic production technology between two periods of time. Similarly to the scale change of technology in the context of static Malmquist index, this component can be interpreted as a bias of dynamic technical change with respect to scale or as a change in the scale of dynamic technology. Scale change of dynamic technology indicates in practice whether new technologies bring a firm closer to or further away from the dynamic frontier in CRS.

Finally, note that the results of the dynamic Luenberger indicator and its components that are greater (lower) than zero indicate increases (decreases) in productivity and its components.

\subsection{Computation of dynamic Luenberger indicator and its decomposition indicators using Data Envelopment Analysis}

This study uses DEA to estimate the dynamic directional input distance functions that build up the dynamic Luenberger indicator and its components (Charnes et al. 1978; Banker et al. 
1984). In particular, eight linear programs need to be solved for each firm: four are singleperiod dynamic directional input distance functions (for time $t$ and $t+1$, each under CRS and VRS), and the other four are mixed-period dynamic directional input distance functions (for technology in time $t$ and observations in time $t+1$, and for technology in time $t+1$ and observations in time $t$, each under CRS and VRS). To compute the dynamic directional input distance function for time $t$ in VRS technology, the following model needs to be solved:

$$
\begin{aligned}
& \vec{D}_{t}^{i}\left(\mathbf{y}_{t}, \mathbf{k}_{t}, \mathbf{x}_{t}, \mathbf{I}_{t} ; \mathbf{g}_{x}, \mathbf{g}_{I} \mid V R S\right)=\max _{\beta, \gamma} \beta \\
& \text { s.t. } \\
& \mathbf{y}_{t m} \leq \sum_{j=1}^{J} \boldsymbol{\gamma}^{j} \mathbf{y}_{t m}^{j}, \quad m=1, \ldots, M ; \\
& \sum_{j=1}^{J} \boldsymbol{\gamma}^{j} \mathbf{x}_{t n}^{j} \leq \mathbf{x}_{t n}-\beta \mathbf{g}_{x_{n}}, \quad n=1, \ldots, N ; \\
& \mathbf{I}_{t f}+\beta \mathbf{g}_{I_{f}}-\delta_{f} \mathbf{k}_{t f} \leq \sum_{j=1}^{J} \boldsymbol{\gamma}^{j}\left(\mathbf{I}_{t f}^{j}-\delta_{f} \mathbf{k}_{t f}^{j}\right), \quad f=1, \ldots, F ; \\
& \sum_{j=1}^{J} \boldsymbol{\gamma}^{j}=1 \\
& \boldsymbol{\gamma}^{j} \geq 0, \quad j=1, \ldots, J .
\end{aligned}
$$

where $\gamma$ is an intensity vector of firm weights, and $\delta$ is a firm-specific depreciation of capital. To estimate dynamic directional input distance function for time $t+1, t+1$ needs to be used instead of $t$ in (11).

A mixed-period dynamic directional input distance function evaluating observations at time $t$ relative to the technology at time $t+1$ in VRS is estimated using the following program:

$$
\begin{aligned}
& \vec{D}_{t+1}^{i}\left(\mathbf{y}_{t}, \mathbf{k}_{t}, \mathbf{x}_{t}, \mathbf{I}_{t} ; \mathbf{g}_{x}, \mathbf{g}_{I} \mid V R S\right)=\max _{\beta, \gamma} \beta \\
& \text { s.t. } \\
& \mathbf{y}_{t m} \leq \sum_{j=1}^{J} \boldsymbol{\gamma}^{j} \mathbf{y}_{t+1 m}^{j}, \quad m=1, \ldots, M ; \\
& \sum_{j=1}^{J} \boldsymbol{\gamma}^{j} \mathbf{x}_{t+1 n}^{j} \leq \mathbf{x}_{t n}-\beta \mathbf{g}_{x_{n}}, \quad n=1, \ldots, N ; \\
& \mathbf{I}_{t f}+\beta \mathbf{g}_{I_{f}}-\delta_{f} \mathbf{k}_{t f} \leq \sum_{j=1}^{J} \boldsymbol{\gamma}^{j}\left(\mathbf{I}_{t+1 f}^{j}-\delta_{f} \mathbf{k}_{t+1 f}^{j}\right), \quad f=1, \ldots, F ; \\
& \sum_{j=1}^{J} \boldsymbol{\gamma}^{j}=1 \\
& \boldsymbol{\gamma}^{j} \geq 0, \quad j=1, \ldots, J .
\end{aligned}
$$

The second mixed-period dynamic directional input distance function evaluating observations at time $t+1$ relative to the technology at time $t$ is computed analogously to (12). 
Finally, to compute dynamic directional input distance functions in CRS, the constraint $\sum_{j=1}^{J} \gamma^{j}=1$ needs to be removed from (11) and (12) and their variations.

It is important to mention that, in the DEA context, the static directional distance function can yield infeasible results for intertemporal analysis, which translates to indeterminateness of static Luenberger indicator (Briec and Kerstens 2009a, b). In particular, Briec and Kerstens (2009a) showed that mixed-period directional distance function may be infeasible, but also single-period directional distance functions in the case when the output direction vector is non-zero and the number of inputs is larger than or equal to two, or the directional input vector is not of full dimension whenever the output direction is null. These facts obviously translate to dynamic directional distance function, which also suffers from the problem of infeasibility.

\section{Description of the data}

The dataset used for estimations was obtained from the AMADEUS database. This database is prepared by Bureau van Dijk and its coverage is (mainly) accounting information for European firms. The final dataset used in this study concerns meat manufacturing firms (NACE Rev. 2 code 10.1), fruit and vegetable processing firms (NACE Rev. 2 code 10.3), dairy manufacturing firms (NACE Rev. 2 code 10.5), and bakery and farinaceous products manufacturing firms (NACE Rev. 2 code 10.7); the dataset includes 18 countries belonging to the European Union (EU) and covers the period from 2005 to 2012. The firms in these countries are grouped into three regions: Eastern EU firms (Bulgaria, Croatia, Czech Republic, Estonia, Hungary, Poland, Romania, Slovakia, and Slovenia), Southern EU firms (Italy, Portugal, and Spain), and Western EU firms (Austria, Belgium, Finland, France, Germany, and Sweden). All of these countries are the main food producers in Europe. The final dataset was obtained in two steps. First, firms with missing observations were removed. Because DEA is known to be sensitive to the presence of outliers, outliers were removed from the sample in the second step, following the procedure of Simar (2003). The final dataset is unbalanced and contains 47,330 observations for meat manufacturing firms, 16,268 observations for fruit and vegetables processing firms, 21,394 observations for dairy manufacturing firms, and 49,864 observations for bakery manufacturing firms.

The DEA model used to compute dynamic productivity growth and its components distinguishes one output (revenue), one quasi-fixed input (fixed assets), two variable inputs (employee costs and material costs), and one type of investment (gross investments in fixed assets). All variables are in monetary units and are expressed in the local currencies and current prices. To make them comparable across countries and years, the variables are adjusted applying the purchasing power parity (PPP) of the local currency to the US dollar and are deflated using price indices (constant prices of 2004). Firms within different industries typically produce different type of outputs; however, due to the limitations of the dataset, which do not report the revenues from different outputs, the data on aggregated revenue is used instead. Revenue is obtained directly from firms' profit and loss accounts in AMADEUS and is deflated using the producer price index for food manufacturing. Fixed assets were taken directly from the firms' balance sheets and were deflated using the producer price index for capital goods. Employee costs and material costs are also taken directly from firms' profit and loss accounts and are deflated using the labour cost index in industry and the producer price index for non-durable consumer goods, respectively. Gross investments in fixed assets in year $t$ were calculated as the beginning value of fixed assets in year $t+1$, minus the beginning value of fixed assets in year $t$, plus the beginning value of depreciation in year $t+1$, 
Table 2 Means and standard deviations for the data for each European food manufacturing sector, 2005-2012 (thousands of PPP, as of 2004)

\begin{tabular}{|c|c|c|c|c|c|c|}
\hline & Fixed assets & $\begin{array}{l}\text { Employee } \\
\text { costs }\end{array}$ & $\begin{array}{l}\text { Material } \\
\text { costs }\end{array}$ & Revenue & Investments & $\begin{array}{l}\text { No. of } \\
\text { observations }\end{array}$ \\
\hline \multicolumn{7}{|l|}{ Meat } \\
\hline Eastern & $\begin{array}{l}6913.529 \\
(16,623.608)\end{array}$ & $\begin{array}{l}1514.494 \\
(3184.870)\end{array}$ & $\begin{array}{l}19,557.991 \\
(35,335.134)\end{array}$ & $\begin{array}{l}25,315.765 \\
(44,283.151)\end{array}$ & $\begin{array}{l}1393.922 \\
(4989.096)\end{array}$ & 9714 \\
\hline Southern & $\begin{array}{l}5885.539 \\
(37,845.885)\end{array}$ & $\begin{array}{l}1800.341 \\
(9618.220)\end{array}$ & $\begin{array}{l}14,650.680 \\
(50,549.997)\end{array}$ & $\begin{array}{l}19,941.740 \\
(73,585.570)\end{array}$ & $\begin{array}{l}1164.965 \\
(11,248.445)\end{array}$ & 21,200 \\
\hline Western & $\begin{array}{l}4266.145 \\
(27,838.281)\end{array}$ & $\begin{array}{l}3162.044 \\
(13,248.774)\end{array}$ & $\begin{array}{l}20,770.198 \\
(95,589.279)\end{array}$ & $\begin{array}{l}29,397.406 \\
(128,587.860)\end{array}$ & $\begin{array}{l}942.344 \\
(7684.818)\end{array}$ & 16,416 \\
\hline \multicolumn{7}{|c|}{ Fruit and vegetables } \\
\hline Eastern & $\begin{array}{l}9390.114 \\
(32,276.891)\end{array}$ & $\begin{array}{l}1427.657 \\
(5019.545)\end{array}$ & $\begin{array}{l}14,474.787 \\
(30,163.706)\end{array}$ & $\begin{array}{l}20,626.280 \\
(42,069.231)\end{array}$ & $\begin{array}{l}1669.920 \\
(4761.487)\end{array}$ & 3186 \\
\hline Southern & $\begin{array}{l}7699.914 \\
(34,251.148)\end{array}$ & $\begin{array}{l}2203.357 \\
(12,583.351)\end{array}$ & $\begin{array}{l}12,827.085 \\
(46,025.273)\end{array}$ & $\begin{array}{l}21,204.403 \\
(103,010.358)\end{array}$ & $\begin{array}{l}1577.666 \\
(10,004.211)\end{array}$ & 9714 \\
\hline Western & $\begin{array}{l}10,884.086 \\
(30,212.735)\end{array}$ & $\begin{array}{l}4408.943 \\
(10,390.283)\end{array}$ & $\begin{array}{l}23,098.604 \\
(51,775.744)\end{array}$ & $\begin{array}{l}37,217.488 \\
(80,757.149)\end{array}$ & $\begin{array}{l}2179.878 \\
(7573.373)\end{array}$ & 3368 \\
\hline \multicolumn{7}{|l|}{ Dairy } \\
\hline Eastern & $\begin{array}{l}11,838.015 \\
(43,447.811)\end{array}$ & $\begin{array}{l}2177.746 \\
(4806.274)\end{array}$ & $\begin{array}{l}31,783.931 \\
(83,526.058)\end{array}$ & $\begin{array}{l}42,050.631 \\
(106,255.064)\end{array}$ & $\begin{array}{l}2933.217 \\
(24,219.234)\end{array}$ & 4478 \\
\hline Southern & $\begin{array}{l}9812.293 \\
(71,626.650)\end{array}$ & $\begin{array}{l}2792.598 \\
(19,379.916)\end{array}$ & $\begin{array}{l}19,201.154 \\
(97,056.328)\end{array}$ & $\begin{array}{l}30,251.943 \\
(180,170.693)\end{array}$ & $\begin{array}{l}1667.388 \\
(13,202.008)\end{array}$ & 11,268 \\
\hline Western & $\begin{array}{l}12,423.144 \\
(45,622.867)\end{array}$ & $\begin{array}{l}5780.746 \\
(18,928.545)\end{array}$ & $\begin{array}{l}55,345.949 \\
(182355.144)\end{array}$ & $\begin{array}{l}74,188.855 \\
(241625.659)\end{array}$ & $\begin{array}{l}2769.090 \\
(15294.038)\end{array}$ & 5648 \\
\hline \multicolumn{7}{|l|}{ Bakery } \\
\hline Eastern & $\begin{array}{l}2330.813 \\
(8060.116)\end{array}$ & $\begin{array}{l}732.090 \\
(1910.399)\end{array}$ & $\begin{array}{l}3078.232 \\
(8955.085)\end{array}$ & $\begin{array}{l}5431.735 \\
(14,935.538)\end{array}$ & $\begin{array}{l}546.494 \\
(2088.603)\end{array}$ & 15,124 \\
\hline Southern & $\begin{array}{l}4736.968 \\
(38,566.641)\end{array}$ & $\begin{array}{l}1599.550 \\
(7845.634)\end{array}$ & $\begin{array}{l}4948.877 \\
(28,121.338)\end{array}$ & $\begin{array}{l}10,335.088 \\
(68,132.441)\end{array}$ & $\begin{array}{l}964.589 \\
(7946.472)\end{array}$ & 19,750 \\
\hline Western & $\begin{array}{l}2941.123 \\
(16,460.814)\end{array}$ & $\begin{array}{l}2360.646 \\
(10,386.614)\end{array}$ & $\begin{array}{l}4534.515 \\
(23,411.886)\end{array}$ & $\begin{array}{l}10,734.637 \\
(57,628.242)\end{array}$ & $\begin{array}{l}647.134 \\
(4504.234)\end{array}$ & 14,990 \\
\hline
\end{tabular}

Standard deviations are in parentheses

where depreciation was obtained directly from the firms' profit and loss accounts. Gross investments were deflated using the producer price index for capital goods. The price indices were obtained from Eurostat (2016c) and vary over years and different countries.

Table 2 provides the means and standard deviations for inputs, output, and investments for every food manufacturing sector and separately for Western, Eastern and Southern European regions. The following observations can be made regarding the data in the table. First, the data shows that standard deviations of all variables relative to their respective means are relatively high; this highlights the wide variation in the sample, which could be due to the fact that the dataset includes firms of different sizes. Second, the reported statistics show substantial differences in the average values of variables between European regions, regardless of whether the food manufacturing sector is considered. 


\section{Results}

Dynamic productivity change indicators are generated separately for the samples of food manufacturing subsectors (meat, fruit and vegetable, dairy, and bakery), for each period separately (from 2005/2006 till 2011/2012) and with regard to region-specific frontier (Eastern, Southern, and Western regions) because it is reasonable to assume that technology differs between EU regions. The directional vector used is the quantity of variable inputs for inputs $\left(\mathbf{g}_{x}\right)$ and $20 \%$ of the size of the capital stock for investments $\left(\mathbf{g}_{I}\right)$. The infeasibilities encountered in estimations account for (percentage of sample size): $3 \%$ for meat, $8 \%$ for fruit and vegetables, $7 \%$ for dairy, and 3\% for bakery. Following the usual treatment in the efficiency and productivity literature, infeasible observations are removed from the sample used to compute the average values of indicators. Table 3 reports the arithmetic means of dynamic productivity change and its decomposition indicators for the whole time period 2005/20062011/2012. The significance of differences in indicators between regions, as well as between food sectors, is tested using Simar and Zelenyuk's (2006) test.

The results in Table 3 indicate that, on average, dynamic productivity declined over time in almost all of the analyzed cases (industries/regions), with the exception of Eastern European firms engaged in the sectors of fruit and vegetables, dairy, and bakery. Some explanation for the decline in productivity can be proposed, such as switches in demand for healthy and socially responsible food products observed in this sector (that is, the emergence of clients who are more costly to serve), or the impact of EU regulations regarding food safety, which have increased production costs.

The results also show that the main source of dynamic productivity decline highlighted above (that is, of firms in all regions in meat manufacturing and in the Southern and Western regions in fruit and vegetables, dairy, and bakery) is the technological part of the dynamic Luenberger indicator; that is, the indicators of dynamic technical change and scale change of dynamic production technology. On average, the technical regress or negative change in scale change of dynamic production technology is observed, or both indexes have a negative sign. That could be a direct consequence of the aforementioned switch in demand and regulation, which could cause situations in which some technologies are no longer available for firms to exploit, resulting in technical regress. This has occurred in parallel to positive change in the dynamic technical inefficiency indicator; that is, the average gap between efficient and inefficient firms has become smaller over time. The globalization and liberalization of the food sector, along with increased competition that has pushed the firms to improve their efficiency, can provide some explanation for this finding. On the contrary, the results for the bakery industry in the Southern and Western regions suggest that the productivity decline is not only due to the technological part of the dynamic Luenberger indicator, but also to the fact that firms, on average, become less technically efficient.

The results indicate that the dynamic productivity gains in Eastern European firms representing the fruit and vegetable, dairy, and bakery sectors can be explained by increases in the inefficiency part of dynamic Luenberger indicator; that is, the indicators of dynamic technical inefficiency change and dynamic scale inefficiency change. In particular, the technical inefficiency change contribution is positive, on average, regardless of the sector; the same applies to scale inefficiency change contribution in the case of fruit and vegetables sector.

Finally, the magnitudes of changes in the indicators in the table suggest that the changes in dynamic productivity are relatively small, with the components of dynamic technical inefficiency change and dynamic technical change showing more substantial values.

Collectively, the results in Table 3 seem to indicate technical regress and advances in dynamic technical inefficiency change in almost all sectors and regions of food manufactur- 
Table 3 Dynamic productivity growth and its decomposition by food manufacturing sector, 2005/2006$2011 / 2012$

\begin{tabular}{|c|c|c|c|c|c|}
\hline Sector and region & $\begin{array}{l}\text { Dynamic } \\
\text { productivity } \\
\text { change }\end{array}$ & $\begin{array}{l}\text { Dynamic } \\
\text { inefficiency } \\
\text { change } \\
\text { under VRS }\end{array}$ & $\begin{array}{l}\text { Dynamic scale } \\
\text { inefficiency } \\
\text { change }\end{array}$ & $\begin{array}{l}\text { Dynamic } \\
\text { technical } \\
\text { change } \\
\text { under VRS }\end{array}$ & $\begin{array}{l}\text { Scale change } \\
\text { of dynamic } \\
\text { technology }\end{array}$ \\
\hline \multicolumn{6}{|l|}{ Meat } \\
\hline Eastern & -0.003 & 0.054 & -0.006 & -0.055 & 0.004 \\
\hline Southern & -0.003 & 0.008 & 0.001 & -0.012 & 0.000 \\
\hline Western & -0.001 & 0.008 & -0.007 & -0.011 & 0.009 \\
\hline $\begin{array}{l}\text { Significance of } \\
\text { differences between } \\
\text { regions }\end{array}$ & $a, b, c$ & $a, b, c$ & $a, b, c$ & $a, b, c$ & $a, b, c$ \\
\hline \multicolumn{6}{|l|}{ Fruit and vegetables } \\
\hline Eastern & 0.001 & 0.029 & 0.018 & -0.027 & -0.019 \\
\hline Southern & -0.004 & 0.005 & 0.013 & -0.010 & -0.012 \\
\hline Western & -0.005 & -0.005 & 0.009 & -0.002 & -0.007 \\
\hline $\begin{array}{l}\text { Significance of } \\
\text { differences between } \\
\text { regions }\end{array}$ & $a, b, c$ & $a, b, c$ & $a, b, c$ & $a, b, c$ & $a, b, c$ \\
\hline \multicolumn{6}{|l|}{ Dairy } \\
\hline Eastern & 0.002 & 0.058 & -0.011 & -0.057 & 0.012 \\
\hline Southern & -0.004 & 0.008 & 0.010 & -0.013 & -0.009 \\
\hline Western & -0.003 & 0.007 & 0.004 & -0.011 & -0.003 \\
\hline $\begin{array}{l}\text { Significance of } \\
\text { differences between } \\
\text { regions }\end{array}$ & $a, b$ & $a, b, c$ & $a, b, c$ & $a, b, c$ & $a, b, c$ \\
\hline \multicolumn{6}{|l|}{ Bakery } \\
\hline Eastern & 0.003 & 0.016 & -0.006 & -0.015 & 0.008 \\
\hline Southern & -0.005 & -0.034 & 0.028 & 0.030 & -0.029 \\
\hline Western & -0.003 & -0.001 & 0.011 & -0.004 & -0.009 \\
\hline $\begin{array}{l}\text { Significance of } \\
\text { differences between } \\
\text { regions }\end{array}$ & $a, b, c$ & $a, b, c$ & $a, b, c$ & $a, b, c$ & $a, b, c$ \\
\hline $\begin{array}{l}\text { Significance of } \\
\text { differences between } \\
\text { sectors (Eastern) }\end{array}$ & $d, e, f, h, i$ & $d, e, f, g, h, i$ & $d, e, f, g, h, i$ & $d, e, f, g, h, i$ & $d, e, f, g, h, i$ \\
\hline $\begin{array}{l}\text { Significance of } \\
\text { differences between } \\
\text { sectors (Western) }\end{array}$ & $d, e, f, g, h, i$ & $d, e, f, g, h, i$ & $d, e, f, g, h, i$ & $d, e, f, g, h, i$ & $d, e, f, g, h, i$ \\
\hline $\begin{array}{l}\text { Significance of } \\
\text { differences between } \\
\text { sectors (Southern) }\end{array}$ & $d, e, f, g, h, i$ & $d, e, f, g, h, i$ & $d, e, f, g, h, i$ & $d, e, f, g, h, i$ & $d, e, f, g, h, i$ \\
\hline
\end{tabular}

All differences are reported at the critical $1 \%$ level; $a$-significant differences between Eastern and Southern; $b$-significant differences between Eastern and Western; $c$-significant differences between Southern and Western; $d$-significant differences between meat and fruit and vegetables; $e$ - significant differences between meat and dairy; $f$-significant differences between meat and bakery; $g$-significant differences fruit and vegetables, and dairy; $h$-significant differences between fruit and vegetables and bakery; $i$-significant differences between dairy and bakery 
Table 4 Evolution of dynamic productivity growth and its decomposition in the meat manufacturing sector

\begin{tabular}{lccccc}
\hline Region & $\begin{array}{l}\text { Dynamic } \\
\text { productivity } \\
\text { change }\end{array}$ & $\begin{array}{l}\text { Dynamic } \\
\text { inefficiency } \\
\text { change } \\
\text { under VRS }\end{array}$ & $\begin{array}{l}\text { Dynamic } \\
\text { scale } \\
\text { inefficiency } \\
\text { change }\end{array}$ & $\begin{array}{l}\text { Dynamic } \\
\text { technical } \\
\text { change } \\
\text { under VRS }\end{array}$ & $\begin{array}{l}\text { Scale change } \\
\text { of dynamic } \\
\text { technology }\end{array}$ \\
\hline Eastern & & & & & \\
2005/2006 & 0.002 & 0.124 & 0.035 & -0.118 & -0.039 \\
2006/2007 & -0.001 & -0.132 & -0.072 & 0.137 & 0.066 \\
$2007 / 2008$ & -0.004 & -0.044 & 0.014 & 0.041 & -0.015 \\
$2008 / 2009$ & 0.001 & 0.083 & 0.041 & -0.075 & -0.048 \\
$2009 / 2010$ & -0.004 & -0.027 & -0.024 & 0.024 & 0.023 \\
$2010 / 2011$ & -0.010 & 0.129 & -0.008 & -0.144 & 0.013 \\
$2011 / 2012$ & 0.005 & 0.214 & -0.032 & -0.209 & 0.032 \\
Southern & & & & & \\
$2005 / 2006$ & 0.003 & -0.016 & 0.111 & 0.026 & -0.118 \\
$2006 / 2007$ & -0.009 & -0.054 & -0.011 & 0.045 & 0.011 \\
$2007 / 2008$ & -0.011 & 0.008 & 0.039 & -0.033 & -0.025 \\
$2008 / 2009$ & 0.005 & -0.009 & -0.038 & 0.017 & 0.035 \\
$2009 / 2010$ & -0.002 & 0.003 & 0.020 & -0.004 & -0.021 \\
$2010 / 2011$ & 0.000 & 0.073 & -0.045 & -0.074 & 0.046 \\
$2011 / 2012$ & -0.002 & 0.018 & -0.020 & -0.021 & 0.021 \\
Western & & & -0.021 & \\
$2005 / 2006$ & 0.003 & -0.045 & 0.012 & 0.047 & -0.011 \\
$2006 / 2007$ & -0.005 & 0.009 & 0.002 & -0.015 & -0.001 \\
$2007 / 2008$ & -0.015 & 0.054 & -0.020 & -0.070 & 0.021 \\
$2008 / 2009$ & 0.022 & 0.023 & -0.009 & -0.004 & 0.012 \\
$2009 / 2010$ & 0.005 & 0.038 & -0.001 & -0.034 & 0.002 \\
$2010 / 2011$ & -0.013 & -0.031 & -0.018 & 0.014 & 0.022 \\
$2011 / 2012$ & -0.006 & 0.003 & -0.015 & -0.012 & 0.018 \\
\hline & & & & & \\
\hline
\end{tabular}

ing. In most of the cases, the positive dynamic technical inefficiency change fails to offset negative dynamic technical change, meaning that, on average, productivity declines in the analyzed period. The exceptions from these trends are presented for some sectors (bakery) and regions (Eastern Europe). When attempting to explain the bakery industry different performance, it should be noted that this industry is different from the other food sectors in terms of its large employment resulting in very low labor productivity. The different performance of the food manufacturing sector in Eastern European countries can be associated with the different characteristics that that this sector in this region has compared to its Western and Southern counterparts; for example it has much lower market share and turnover (Tacken et al. 2009; Wijnands et al. 2007).

The general results contained in Table 3 are analyzed in more detail below by looking at the evolution over time of dynamic indicators. Such analysis also makes it possible to evaluate more closely the impact of recent food industry shocks such as the financial crisis or volatility of agricultural commodity prices that occurred in 2008 and 2007, respectively. Tables 4, 5, 6 and 7 summarize these results for each region for meat manufacturing, fruit and vegetable processing, dairy manufacturing, and bakery manufacturing, respectively. 
Table 5 Evolution over time of dynamic productivity growth and its decomposition in the fruit and vegetable processing sector

\begin{tabular}{lccccc}
\hline Region & $\begin{array}{l}\text { Dynamic } \\
\text { productivity } \\
\text { change }\end{array}$ & $\begin{array}{l}\text { Dynamic } \\
\text { inefficiency } \\
\text { change } \\
\text { under VRS }\end{array}$ & $\begin{array}{l}\text { Dynamic } \\
\text { scale } \\
\text { inefficiency } \\
\text { change }\end{array}$ & $\begin{array}{l}\text { Dynamic } \\
\text { technical } \\
\text { change } \\
\text { under VRS }\end{array}$ & $\begin{array}{l}\text { Scale change } \\
\text { of dynamic } \\
\text { technology }\end{array}$ \\
\hline Eastern & & & & & \\
$2005 / 2006$ & 0.006 & 0.017 & -0.034 & 0.001 & 0.022 \\
$2006 / 2007$ & 0.016 & -0.083 & 0.063 & 0.102 & -0.066 \\
$2007 / 2008$ & -0.010 & 0.015 & 0.035 & -0.034 & -0.026 \\
$2008 / 2009$ & -0.011 & 0.088 & -0.052 & -0.098 & 0.051 \\
$2009 / 2010$ & 0.004 & 0.011 & -0.030 & -0.003 & 0.026 \\
$2010 / 2011$ & 0.002 & 0.090 & 0.088 & -0.087 & -0.089 \\
$2011 / 2012$ & 0.001 & 0.011 & 0.049 & -0.012 & -0.047 \\
Southern & & & & & \\
$2005 / 2006$ & 0.000 & -0.053 & -0.030 & 0.056 & 0.027 \\
$2006 / 2007$ & -0.003 & 0.006 & 0.014 & -0.005 & -0.018 \\
$2007 / 2008$ & -0.008 & 0.006 & -0.031 & -0.020 & 0.037 \\
$2008 / 2009$ & 0.000 & -0.047 & 0.062 & 0.053 & -0.068 \\
$2009 / 2010$ & 0.003 & 0.089 & -0.045 & -0.086 & 0.045 \\
$2010 / 2011$ & -0.012 & 0.009 & 0.063 & -0.025 & -0.059 \\
$2011 / 2012$ & -0.006 & 0.014 & 0.037 & -0.025 & -0.032 \\
Western & & -0.025 & & 0.011 \\
$2005 / 2006$ & -0.012 & -0.021 & -0.012 & 0.010 & -0.147 \\
$2006 / 2007$ & -0.012 & 0.048 & 0.148 & -0.061 & 0.023 \\
$2007 / 2008$ & -0.015 & -0.011 & 0.025 & -0.006 & 0.017 \\
$2008 / 2009$ & 0.023 & -0.022 & -0.013 & 0.043 & 0.022 \\
$2009 / 2010$ & 0.001 & 0.014 & -0.016 & -0.014 & -0.007 \\
$2010 / 2011$ & -0.027 & -0.024 & -0.018 & 0.018 & \\
$2011 / 2012$ & -0.004 & -0.021 & -0.049 & & \\
\hline & & & & & \\
\hline
\end{tabular}

Table 4 shows that Eastern and Western European meat manufacturing firms in the $2008 / 2009$ period (the beginning of the financial crisis) increased their contribution of dynamic technical inefficiency change and decreased their contribution of dynamic technical change to productivity growth. Scale components of inefficiency and technology show the same patterns as their technical inefficiency and technology counterparts for Eastern Europe, while firms in Western Europe worsened their scale inefficiency and improved their scale of technology. Southern European firms in the same period experienced a decrease in dynamic technical efficiency and technical progress. In the years thereafter, however, they managed to increase their dynamic technical efficiency at the offset of technical regress.

Turning to the results for the fruit and vegetable sector in Table 5, the remarkable pattern of positive dynamic technical inefficiency change and negative dynamic technical change is observed for Eastern European firms following the start of the financial crisis; that is, from 2008/2009. Southern European firms found that their dynamic technical efficiency decreased in 2008/2009, but increased in the subsequent periods. The opposite pattern for these firms is 
Table 6 Evolution over time of dynamic productivity growth and its decomposition in the dairy manufacturing sector

\begin{tabular}{|c|c|c|c|c|c|}
\hline Region & $\begin{array}{l}\text { Dynamic } \\
\text { productivity } \\
\text { change }\end{array}$ & $\begin{array}{l}\text { Dynamic } \\
\text { inefficiency } \\
\text { change } \\
\text { under VRS }\end{array}$ & $\begin{array}{l}\text { Dynamic } \\
\text { scale } \\
\text { inefficiency } \\
\text { change }\end{array}$ & $\begin{array}{l}\text { Dynamic } \\
\text { technical } \\
\text { change } \\
\text { under VRS }\end{array}$ & $\begin{array}{l}\text { Scale } \\
\text { change of } \\
\text { dynamic } \\
\text { technology }\end{array}$ \\
\hline \multicolumn{6}{|l|}{ Eastern } \\
\hline $2005 / 2006$ & 0.020 & 0.024 & -0.002 & 0.000 & -0.002 \\
\hline $2006 / 2007$ & 0.019 & -0.031 & -0.083 & 0.057 & 0.076 \\
\hline $2007 / 2008$ & -0.011 & 0.099 & -0.033 & -0.116 & 0.039 \\
\hline $2008 / 2009$ & 0.012 & 0.264 & 0.103 & -0.247 & -0.108 \\
\hline $2009 / 2010$ & -0.001 & -0.075 & -0.088 & 0.072 & 0.090 \\
\hline 2010/2011 & -0.009 & 0.058 & 0.001 & -0.077 & 0.009 \\
\hline $2011 / 2012$ & -0.001 & 0.054 & 0.015 & -0.055 & -0.015 \\
\hline \multicolumn{6}{|l|}{ Southern } \\
\hline $2005 / 2006$ & -0.003 & 0.027 & 0.042 & -0.032 & -0.040 \\
\hline $2006 / 2007$ & -0.009 & -0.035 & -0.012 & 0.024 & 0.014 \\
\hline $2007 / 2008$ & -0.018 & -0.026 & -0.022 & 0.012 & 0.018 \\
\hline $2008 / 2009$ & 0.022 & 0.003 & -0.004 & 0.017 & 0.006 \\
\hline $2009 / 2010$ & 0.002 & 0.011 & 0.016 & -0.015 & -0.010 \\
\hline 2010/2011 & -0.013 & 0.054 & 0.042 & -0.070 & -0.039 \\
\hline $2011 / 2012$ & -0.009 & 0.018 & 0.012 & -0.026 & -0.013 \\
\hline \multicolumn{6}{|l|}{ Western } \\
\hline $2005 / 2006$ & 0.004 & -0.100 & -0.072 & 0.102 & 0.074 \\
\hline $2006 / 2007$ & -0.006 & 0.010 & 0.020 & -0.020 & -0.016 \\
\hline $2007 / 2008$ & -0.013 & 0.052 & 0.038 & -0.067 & -0.036 \\
\hline $2008 / 2009$ & 0.017 & 0.047 & 0.017 & -0.030 & -0.017 \\
\hline $2009 / 2010$ & 0.001 & 0.037 & 0.043 & -0.036 & -0.043 \\
\hline 2010/2011 & -0.010 & -0.032 & -0.052 & 0.020 & 0.054 \\
\hline $2011 / 2012$ & -0.012 & 0.026 & 0.034 & -0.039 & -0.033 \\
\hline
\end{tabular}

found for the technical change component. Western European firms experienced losses in the majority of periods for both dynamic technical inefficiency change and dynamic technical change.

The results for the dairy manufacturing sector, shown in Table 6, show that following 2007/2008 and 2008/2009-which mark the beginning of periods of volatility in milk prices and the financial crisis, respectively-firms in all regions found that their dynamic technical inefficiency change increased in most periods, while the trend in dynamic technical change was a downward one. Also, dynamic scale inefficiency change seems to increase in most periods. The finding of the increase in dynamic technical efficiency is not surprising when one considers that costs increased during this period due to the increase in prices of the main input - milk - but that profit margins remained stable during the same time (European Commission 2009). Therefore, there have been some productive efficiencies presented in this sector that allowed profit margins to be maintained. Table 6 also shows some remarkably large changes (of more than 10\%) in dynamic indicators in Eastern Europe in 2008/2009. 
Table 7 Evolution over time of dynamic productivity growth and its decomposition in the bakery manufacturing sector

\begin{tabular}{|c|c|c|c|c|c|}
\hline Region & $\begin{array}{l}\text { Dynamic } \\
\text { productivity } \\
\text { change }\end{array}$ & $\begin{array}{l}\text { Dynamic } \\
\text { inefficiency } \\
\text { change under } \\
\text { VRS }\end{array}$ & $\begin{array}{l}\text { Dynamic } \\
\text { scale } \\
\text { inefficiency } \\
\text { change }\end{array}$ & $\begin{array}{l}\text { Dynamic } \\
\text { technical } \\
\text { change } \\
\text { under VRS }\end{array}$ & $\begin{array}{l}\text { Scale change } \\
\text { of dynamic } \\
\text { technology }\end{array}$ \\
\hline \multicolumn{6}{|l|}{ Eastern } \\
\hline $2005 / 2006$ & 0.020 & 0.004 & -0.038 & 0.025 & 0.029 \\
\hline $2006 / 2007$ & 0.019 & -0.326 & 0.035 & 0.341 & -0.031 \\
\hline $2007 / 2008$ & -0.002 & -0.051 & -0.005 & 0.049 & 0.005 \\
\hline $2008 / 2009$ & -0.010 & 0.156 & -0.040 & -0.170 & 0.044 \\
\hline $2009 / 2010$ & 0.000 & 0.020 & -0.007 & -0.021 & 0.008 \\
\hline 2010/2011 & -0.003 & -0.042 & 0.014 & 0.031 & -0.006 \\
\hline $2011 / 2012$ & 0.001 & 0.270 & -0.003 & -0.267 & 0.001 \\
\hline \multicolumn{6}{|l|}{ Southern } \\
\hline $2005 / 2006$ & -0.003 & -0.024 & -0.016 & 0.027 & 0.010 \\
\hline $2006 / 2007$ & -0.006 & 0.029 & 0.377 & -0.044 & -0.368 \\
\hline $2007 / 2008$ & -0.003 & 0.039 & 0.022 & -0.045 & -0.019 \\
\hline $2008 / 2009$ & 0.002 & -0.069 & -0.007 & 0.088 & -0.010 \\
\hline $2009 / 2010$ & -0.003 & -0.016 & 0.089 & 0.015 & -0.091 \\
\hline $2010 / 2011$ & -0.018 & 0.002 & 0.012 & -0.024 & -0.008 \\
\hline $2011 / 2012$ & -0.008 & -0.155 & -0.114 & 0.144 & 0.117 \\
\hline \multicolumn{6}{|l|}{ Western } \\
\hline $2005 / 2006$ & 0.000 & -0.048 & 0.013 & 0.047 & -0.012 \\
\hline $2006 / 2007$ & -0.008 & -0.020 & 0.012 & 0.009 & -0.009 \\
\hline $2007 / 2008$ & -0.022 & -0.077 & -0.008 & 0.054 & 0.009 \\
\hline $2008 / 2009$ & 0.028 & 0.097 & 0.038 & -0.066 & -0.041 \\
\hline $2009 / 2010$ & 0.008 & 0.020 & -0.008 & -0.015 & 0.011 \\
\hline $2010 / 2011$ & -0.024 & -0.027 & 0.017 & 0.001 & -0.015 \\
\hline $2011 / 2012$ & -0.005 & 0.050 & 0.015 & -0.059 & -0.011 \\
\hline
\end{tabular}

The last set of results are shown in Table 7, for the bakery industry. In 2007/2008, which marks the beginning of volatility in grain and cereals prices on which this sector is strongly reliant, firms in Eastern Europe experienced a decline in dynamic technical change, from which they recovered in subsequent periods, as well as an increase in dynamic technical change, which started to decrease afterwards. A similar pattern can be observed for Western European firms. The dynamic technical efficiency of bakery firms in Southern Europe increased in 2007/2008 and later decreased; these firms also first experienced technical regress that changed into progress in most of periods after 2007/2008.

\section{Conclusions}

This paper has sought to study productivity change of food manufacturing sector in the European Union between 2005 and 2012. Four main sectors have been analyzed in $18 \mathrm{EU}$ 
nations in three regions. This paper adopted a dynamic adjustment perspective and extended the dynamic Luenberger indicator to provide its full decomposition into indicators for which economic interpretation is provided (that is, dynamic technical inefficiency change, dynamic scale inefficiency change, dynamic technical change, and scale change of dynamic technology).

The findings of the study indicate good results of dynamic technical inefficiency change that increases over the analyzed period in almost all sectors and regions of food manufacturing. However, the study also highlights an average technical regress that tends to dominate in all sectors and regions of food industry. Positive dynamic inefficiency change fails to offset negative dynamic technical change, which means that, on average, productivity tends to decline. Some exceptions from these trends are found for some sectors (bakery) and regions (Eastern Europe). The important policy implication that stems from these findings is that incentives should focus on improving the technology employed by food manufacturing firms and promoting investments in newly developed technologies that could induce technical progress. This study also shed light on the performance and productivity change of food manufacturing sector in the context of challenges and shocks that impacted the development of this sector, such as financial crisis and volatility of agricultural commodity prices.

This study has analyzed the productivity change of food manufacturing firms in the European Union with regard to their own group in relation to their EU region. To provide more insights into the performance of this industry and differences between regions and sectors, future research could focus on the development of productivity change indicators that assess firms with regard to common frontiers, as well as relate the group-specific indicators with pooled indicators. Such studies could build on the ideas of metafrontier (Battese et al. 2004) and program and managerial efficiency (Charnes et al. 1981). From an empirical point of view, the current study could be extended to analyze productivity change, taking into account the composition of the sample with regard to size. In the empirical study, more insights could be also obtained by analyzing input- and output-specific components of productivity change. This would also require the development of indicators that can account for both inputs reductions and output augmentations.

Acknowledgements Financial support for this article from the National Science Centre in Poland (Decision Number DEC-2013/11/D/HS4/00252) is gratefully acknowledged. The part of calculations for this article was made at the Wroclaw Centre for Networking and Supercomputing (http://www.wcss.wroc.pl).

Open Access This article is distributed under the terms of the Creative Commons Attribution 4.0 International License (http://creativecommons.org/licenses/by/4.0/), which permits unrestricted use, distribution, and reproduction in any medium, provided you give appropriate credit to the original author(s) and the source, provide a link to the Creative Commons license, and indicate if changes were made.

\section{References}

Aparicio, J., Pastor, J. T., \& Vidal, F. (2016). The weighted additive distance function. European Journal of Operational Research, 254, 338-346.

Aparicio, J., Pastor, J. T., \& Zofío, J. L. (2017). Can Farrell's allocative efficiency be generalized by the directional distance function approach? European Journal of Operational Research, 257, 345-351.

Battese, G. E., Prasada Rao, D. S., \& O’Donnell, Ch J. (2004). A metafrontier production function for estimation of technical efficiencies and technology gaps for firms operating under different technologies. Journal of Productivity Analysis, 21, 91-103.

Bontemps, C., Nauges, C., Réquillart, V., \& Simioni, N. (2012). Food safety regulation and firm productivity: Evidence from the French food industry, IDEI Working Papers. http://www.idei.fr/doc/by/requillart/ foodsafety.pdf. Accessed 10 June 2016. 
Boussemart, J.-P., Briec, W., Kerstens, K., \& Poutineau, J.-C. (2003). Luenberger and Malmquist productivity indices: Theoretical comparisons and empirical illustration. Bulletin of Economic Research, 55, 391-405.

Briec, W. (1998). Hölder distance function and measurement of technical efficiency. Journal of Productivity Analysis, 11, 111-131.

Briec, W., \& Kerstens, K. (2009a). Infeasibility and directional distance functions with application of determinateness of the Luenberger productivity indicator. Journal of Optimization Theory and Applications, $141,55-73$.

Briec, W., \& Kerstens, K. (2009b). The Luenberger productivity indicator: An economic specification leading to infeasibilities. Economic Modelling, 26, 597-600.

Buccola, S., Fujii, Y., \& Xia, Y. (2000). Size and productivity in the US milling and baking industries. American Journal of Agricultural Economics, 82, 865-880.

Chambers, R. G., Chung, Y., \& Färe, R. (1998). Profit, directional distance functions, and Nerlovian efficiency. Journal of Optimization Theory and Applications, 98, 351-364.

Chambers, R. G., Färe, R., \& Grosskopf, S. (1996). Productivity growth in APEC countries. Pacific Economic Review, 1, 181-190.

Chambers, R. G., \& Pope, R. D. (1996). Aggregate productivity measures. American Journal of Agricultural Economics, 78, 1360-1365.

Charnes, A., Cooper, W. W., \& Rhodes, E. (1981). Evaluating program and managerial efficiency: An application of data envelopment analysis to program follow through. Management Science, 27, 668-697.

De Mateo, F., Coelli, T., \& O'Donnell, Ch. (2006). Optimal paths and costs of adjustment in dynamic DEA models: With application to Chilean department stores. Annals of Operations Research, 145, 211-227.

Doucouliagos, H., \& Hone, P. (2001). The efficiency of the Australian dairy processing industry. Australian Journal of Agricultural and Resource Economics, 44, 423-438.

European Commission. (2011). Study on the competitiveness of the European meat processing industry. Luxembourg: Publication Office of the European Union. http://bookshop.europa.eu/en/study-on-thecompetitiveness-of-the-european-meat-processing-industry-pbNB3211640/. Accessed 20 May 2016.

European Commission. (2016). The competitive position of the European food and drink industry. Luxembourg: Publication Office of the European Union. http://ec.europa.eu/DocsRoom/documents/15496/ attachments/1/translations. Accessed 20 May 2016.

Eurostat. (2016a). National accounts. http://ec.europa.eu/eurostat/web/national-accounts/data/database. Accessed 20 May 2016.

Eurostat. (2016b). Structural business statistics. http://ec.europa.eu/eurostat/web/structural-businessstatistics/data/database. Accessed 20 May 2016.

Eurostat. (2016c). Short-term business statistics. http://ec.europa.eu/eurostat/web/short-term-businessstatistics/data/database. Accessed 20 May 2016.

Färe, R., \& Grosskopf, S. (1996). Intertemporal production frontiers: With dynamic DEA. Boston: Kluwer Academic Publishers.

Färe, R., Grosskopf, S., Lindgren, B., \& Roos, P. (1992). Productivity changes in Swedish pharmacies 19801989: A non-parametric Malmquist approach. Journal of Productivity Analysis, 3, 85-101.

Fukuyama, H., \& Weber, W. L. (2017). Measuring bank performance with a dynamic network Luenberger indicator. Annals of Operations Research, 250, 85-104.

Geylani, P. C., \& Stefanou, S. E. (2011). Productivity growth patterns in U.S. dairy products manufacturing. Applied Economics, 43, 3415-3432.

Gregg, D., \& Rolfe, J. (2011). Identifying sources and trends for productivity growth in a sample of Queensland broad-acre beef enterprises. Animal Production Science, 51, 443-453.

Jabir, A., Singh, S. P., \& Ekanem, E. (2009). Efficiency and productivity changes in the Indian food processing industry: Determinants and policy implications. International Food and Agribusiness Management Review, 12, 43-66.

Kao, C. (2013). Dynamic data envelopment analysis: A relational analysis. European Journal of Operational Research, 227, 325-330.

Kapelko, M., Oude Lansink, A., \& Stefanou, S. E. (2014). Assessing dynamic inefficiency of the Spanish construction sector pre- and post-financial crisis. European Journal of Operational Research, 237, 349357.

Kapelko, M., Oude Lansink, A., \& Stefanou, S. (2015a). Effect of food regulation on the Spanish food processing industry. PLOS ONE, 10(6), e0128217. doi:10.1371/journal.pone.0128217.

Kapelko, M., Oude Lansink, A., \& Stefanou, S. E. (2015b). Analyzing the impact of investment spikes on dynamic productivity growth. OMEGA - International Journal of Management Science, 54, 116-124.

Kapelko, M., Oude Lansink, A., \& Stefanou, S. (2016). Investment age and dynamic productivity growth in the Spanish food processing industry. American Journal of Agricultural Economics, 98, 946-961. 
Kapelko, M., Oude Lansink, A., \& Stefanou, S. (2017a). The impact of 2008 financial crisis on dynamic productivity growth of the Spanish food manufacturing industry. Agricultural Economics. doi:10.1111/ agec. 12357.

Kapelko, M., Oude Lansink, A., \& Stefanou, S. (2017b). Assessing the impact of changing economic environment on productivity growth: The case of the Spanish dairy processing industry. Journal of Food Products Marketing, 23, 384-397.

Kim, S., \& Han, G. (2001). A decomposition of total factor productivity growth in Korean manufacturing industries: A stochastic frontier approach. Journal of Productivity Analysis, 16, 269-281.

Kumar, M., \& Basu, P. (2008). Perspectives of productivity growth in Indian food industry: A data envelopment analysis. International Journal of Productivity and Performance Management, 57, 503-522.

Luenberger, D. G. (1992). New optimality principles for economic efficiency and equilibrium. Journal of Optimization Theory and Applications, 75, 221-264.

Luenberger, D. G. (1995). Microeconomic theory. New York: McGraw-Hill.

Lv, W., Hong, X., \& Fang, K. (2015). Chinese regional energy efficiency change and its determinants analysis: Malmquist index and Tobit model. Annals of Operations Research, 228, 9-22.

Morrison Paul, C. J. (1997). Structural change, capital investment and productivity in the food processing industry. American Journal of Agricultural Economics, 79, 110-125.

Morrison Paul, C. J. (2001a). Market and cost structure in the U.S. beef packing industry: A plant-level analysis. American Journal of Agricultural Economics, 83, 64-76.

Morrison Paul, C. J. (2001b). Cost economies and market power: The case of the U.S. meat packing industry. Review of Economics and Statistics, 83, 531-540.

Nemoto, J., \& Goto, M. (1999). Dynamic data envelopment analysis: Modeling intertemporal behavior of a firm in the presence of productive inefficiencies. Economic Letters, 64, 51-56.

Ohlan, R. (2013). Efficiency and total factor productivity growth in Indian dairy sector. Quarterly Journal of International Agriculture, 52, 51-77.

Oude Lansink, A., Stefanou, S. E., \& Serra, T. (2015). Primal and dual dynamic Luenberger productivity indicators. European Journal of Operational Research, 241, 555-563.

Ouellette, P., \& Vierstraete, W. (2010). Malmquist indexes with quasi-fixed inputs: An application to school districts in Québec. Annals of Operations Research, 173, 57-76.

Regulation No 178/2002 of the European Parliament and of the Council of 28 January 2002. http://eurlex.europa.eu/LexUriServ/LexUriServ.do?uri=OJ:L:2002:031:0001:0024:EN:PDF. Accessed 10 June 2016.

Shephard, R. W. (1953). Cost and production functions. Princeton: Princeton University Press.

Silva, E., Oude Lansink, A., \& Stefanou, S. E. (2015). The adjustment-cost model of the firm: Duality and productive efficiency. International Journal of Production Economics, 168, 245-256.

Silva, E., \& Stefanou, S. E. (2003). Nonparametric dynamic production analysis and the theory of cost. Journal of Productivity Analysis, 19, 5-32.

Silva, E., \& Stefanou, S. E. (2007). Dynamic efficiency measurement: Theory and application. American Journal of Agricultural Economics, 89, 398-419.

Simar, L., \& Wilson, P. W. (1998). Productivity growth in industrialized countries. Discussion Paper No. 9810 , Universite Catholique de Louvain, Belgium.

Simar, L. (2003). Detecting outliers in frontier models: A simple approach. Journal of Productivity Analysis, 20, 391-424.

Simar, L., \& Zelenyuk, V. (2006). On testing equality of distributions of technical efficiency scores. Econometric Reviews, 25, 497-522.

Tacken, G. M. L., Banse, M., Batowska, A., Garebroek, C., Nesha Turi, K., Wijnands, J. H. M., \& Poppe, K. J. (2009). Competitiveness of the EU dairy industry. LEI Wageningen UR, The Hague. http://edepot.wur. nl/10766. Accessed 10 June 2016.

Tone, K., \& Tsutsui, M. (2014). Dynamic DEA with network structure: A slacks-based measure approach. Omega, 42, 124-131.

Treadway, A. B. (1970). Adjustment costs and variable inputs in the theory of the competitive firm. Journal of Economic Theory, 2, 329-347.

Vlontzos, G., \& Theodoridis, A. (2013). Efficiency and productivity change in the Greek dairy industry. Agricultural Economics Review, 14, 14-28.

Von Geymueller, P. (2009). Static versus dynamic DEA in electricity regulation: The case of US transmission system operators. Central European Journal of Operations Research, 17, 397-413.

Wheelock, D. C., \& Wilson, P. W. (1999). Technical progress, inefficiency, and productivity change in U.S. banking, 1984-1993. Journal of Money, Credit and Banking, 31, 212-234.

Wijnands, J. H. M., Van der Meulen, B. M. J., \& Poppe, K. J. (2007). Competitiveness of the European food industry: An economic and legal assessment. Luxembourg: Publication Office of the European 
Union. http://bookshop.europa.eu/en/competitiveness-of-the-european-food-industry-pbNB7807110/. Accessed 10 June 2016.

Williams, J., Peypoch, N., \& Pestana Barros, C. (2011). The Luenberger indicator and productivity growth: A note on the European savings banks sector. Applied Economics, 43, 747-755.

Zofio, J. L., \& Lovell, C. A. K. (1998). Yet another Malmquist productivity index decomposition. Mimeo, Department of Economics, Universidad Autónoma de Madrid, Madrid, University of Georgia, Athens, Georgia.

Zofio, J. L. (2007). Malmquist productivity index decompositions: A unifying framework. Applied Economics, $39,2371-2387$. 